\title{
Simplexviruses successfully adapt to their host by fine-tuning immune responses
}

Alessandra Mozzi ${ }^{1 *} \$$, Rachele Cagliani ${ }^{1 *}$, Chiara Pontremoli ${ }^{1}$, Diego Forni ${ }^{1}$, Irma Saulle $^{2,3}$, Marina Saresella ${ }^{4}$, Uberto Pozzoli ${ }^{1}$, Mario Clerici ${ }^{3,4}$, Mara Biasin $^{2}$, Manuela Sironi ${ }^{1}$

* equal contribution

\$ corresponding author

${ }^{1}$ Scientific Institute, IRCCS E. MEDEA, Bioinformatics, 23842 Bosisio Parini, Italy.

${ }^{2}$ Department of Biomedical and Clinical Sciences "L. Sacco", University of Milan, 20157 Milan, Italy.

${ }^{3}$ Department of Physiopathology and Transplantation, University of Milan, 20090 Milan, Italy.

${ }^{4}$ Don C. Gnocchi Foundation ONLUS, IRCCS, Laboratory of Molecular Medicine and Biotechnology, 20148, Milan, Italy.

Corresponding author: Alessandra Mozzi, Bioinformatics - Scientific Institute IRCCS E. MEDEA, 23842 Bosisio Parini, Italy. e-mail: alessandra.mozzi@lanostrafamiglia.it 
bioRxiv preprint doi: https://doi.org/10.1101/2020.07 28.226126; this version posted July 29,2020 . The copyright holder for this preprint (which was not certified by peer review) is the author/funder, who has granted bioRxiv a license to display the preprint in perpetuity. It is made available under aCC-BY-ND 4.0 International license.

\section{Abstract}

3 Primate herpes simplex viruses are relatively harmless to their natural hosts, whereas cross-species

4 transmission can result in severe disease. We performed a genome-wide scan for signals of

5 adaptation of simplexviruses to hominins. We found evidence of positive selection in three

6 glycoproteins, with selected sites located in antigenic determinants. Positively selected non-core

7 proteins were involved in different immune-escape mechanisms. By expressing mutants of one of

8 these proteins (ICP47), we show that the amino acid status at the positively selected sites is

9 sufficient to induce HLA-G. HSV-1/HSV-2 ICP47 induced HLA-G when mutated to recapitulate

10 residues in B virus, whereas the mutated version of B virus ICP47 failed to determine HLA-G

11 expression. Thus, the evolution of ICP47 in HSV-1/HSV-2 determined the loss of an

12 immunosuppressive effect, suggesting that simplexviruses tune immune responses to promote

13 successful co-existence with their hosts. These results also help explain the high pathogenicity of B

14 virus in humans. 
Introduction

Herpes simplex viruses (genus Simplexvirus, family Herpesviridae, order Herpesvirales), are dsDNA viruses that infect mammals, including humans and other primates. They have long genomes of approximately $155 \mathrm{kbp}$, organized into two regions of unique sequence (long (UL) and short (US)) flanked by direct or inverted repeats. The two unique sequences contain the great majority of the protein-coding regions, including core genes, which are shared among herpesviruses, and non-core genes, that are specific for members of the Alphaherpesvirinae subfamily and/or of the Simplexvirus genus only (McGeoch et al., 2006). In analogy to other herpesviruses, the evolutionary history of simplexviruses was mainly characterized by coevolution and codivergence with their hosts (McGeoch et al., 2006). A known exception is represented by human herpes simplex virus 2 (HSV-2), which most likely originated from the cross-species transmission of an ancestor of chimpanzee herpesvirus 1 (PanHV-3) to an ancestor of modern humans, around 1.6 million years ago (Severini et al., 2013; Underdown et al., 2017; Wertheim et al., 2014). Thus, whereas most primates are infected by a single simplexvirus, humans host two: HSV-2 and human herpes simplex virus 1 (HSV-1). These viruses are present at high prevalence in human populations. Estimates vary with geography and reach 67\% (HSV-1) and 11\% (HSV-2) of the world population (Looker et al., 2015a; Looker et al., 2015b). Even if HSV-1 is primarily responsible for oro-facial lesions and HSV-2 for genital herpes (Arvin et al., 2007), both viruses can establish latency in trigeminal and lumbosacral ganglia, resulting in life-long infection (Arvin et al., 2007). Whereas a relatively low proportion of infected individuals show clinical manifestations during primary infection or reactivation (Tognarelli et al., 2019), simplexviruses can occasionally determine severe diseases such as infectious blindness, acute encephalitis, and neonatal invasive infection (Farooq and Shukla, 2012; Whitley, 2004). In non-human primates (NHP), simplexvirus infections show symptoms and seroprevalence generally comparable to those of HSV-1 and HSV-2, and these viruses are species-specific in natural settings (Eberle and Jones-Engel, 2017). This feature, together with the near commensal relationship with their hosts, is in line with long-standing virus-host coevolution. Indeed, the consequences arising from disruption of the delicate balance established during millions of years of coexistence are evident when cross-species transmissions occur. For instance, macacine herpesvirus 1 (McHV1, also known as B virus) is almost asymptomatic in macaques, but infection of humans or African monkeys results in a severe, often fatal form of encephalomyelitis (Eberle and Jones-Engel, 2017; Loomis et al., 1981; Tischer and Osterrieder, 2010; Wilson et al., 1990). 
bioRxiv preprint doi: https://doi org/10.1101/2020.07 28.226126: this version posted July 29.2020 . The copyright holder for this preprint (which was not certified by peer review) is the author/funder, who has granted bioRxiv a license to display the preprint in perpetuity. It is made available under aCC-BY-ND 4.0 International license.

Likewise, the transmission of HSV-1 from humans to marmosets or other New World monkeys is almost invariably fatal (Azab et al., 2018; Tischer and Osterrieder, 2010). These examples clearly testify how the viral and host genomes interact to determine the outcome of infection and highlight the potential zoonotic threat posed by simplexviruses. This also implies that simplexviruses must have adapted to their hosts and that the signatures of such adaptation may be detected using molecular evolution approaches. We thus performed a genome-wide scan of positive selection to identify variants in simplexvirus coding genes that arose during adaptation to the hominin lineage. As a proof of concept, we tested the functional effect of selected variants in US12, which encodes the ICP47 TAP inhibitor, a modulator of immune response.

\section{Results}

\section{Selective patterns of catarrhini-infecting simplexvirus coding genes}

We first explored the selective patterns of primate simplexvirus coding genes. We thus analyzed 6 complete genomes of simplexviruses that infect different primates, from hominins (HSV-1, HSV-2, and $\mathrm{ChHV}$ ) to Old World African and Asian monkeys (CeHV-2, PaHV-2, and McHV-1) (Figure 1A, Table S1).

Because high sequence diversity can affect evolutionary inference, viruses that infect New World primates were excluded from these analyses. Analysis of selective patterns was performed for all coding genes with reliable one-to-one orthologs. Gene sequences were rigorously filtered to ensure high quality alignments (see Materials and Methods). Genes for which few orthologous sequences were retrieved or with extended overlapping ORFs, were discarded (Table S2). The average non-synonymous substitution/synonymous substitution rate ( $\mathrm{dN} / \mathrm{dS}$, also referred to as $\omega)$ was calculated for the resulting 65 genes (Table S3). Comparison of $\omega$ values among core genes (conserved among Herpesviridae, $n=38$ ) and non-core genes (specific to simplexviruses, $n=27$ ) indicated that these latter show lower evolutionary constraint (Wilcoxon Rank Sum test, $p=0.011$ ) (Figure 1B, Table S3).

\section{Adaptive evolution in the hominin-infecting simplexvirus lineage}

In order to assess whether adaptation to hominins drove the evolution of specific simplexvirus coding genes, we applied a branch-site test (Zhang et al., 2005) to an extended phylogeny of 53 viruses that infect hominins, Old World African monkeys, and Old world Asian monkeys (Figure 1A, Table S1). In the branch-site test, the branches of the tree are divided a priori into foreground and 
81 background lineages, and models that allow or disallow positive selection on the foreground

82 lineage(s) are compared. The branch-site test can thus detect lineage-specific selected genes and

83 sites (episodic positive selection). Herein, we set the branch leading to the hominin-infecting

84 simplexviruses as foreground (Figure 1A).

85 After accounting for recombination (see Materials and Methods), we found evidence of adaptive evolution for 11 genes (16.9\%). Positive selection in hominin simplexviruses similarly targeted core and non-core genes (selected fraction $=15.8 \%$ and $18.5 \%$ ), irrespective of the higher selective constraint observed in core genes during viral evolution in catarrhini (Table S4).

We next analyzed positively selected sites. To be conservative, these were detected by the intersection of two approaches (see Materials and Methods). Among the core genes, we found evidence of episodic positive selection for three glycoproteins: gB (UL27), gH (UL22) and gM (UL10) (Figure 2 and Figure S1). UL27 encodes the viral envelope glycoprotein B (gB), which is a major target antigen in herpesviruses (Malito et al., 2018). Both selected sites in gB are located in the ectodomain (Figure 2) and one of them, A334, is part of an epitope recognized by the SS55 neutralizing antibody (Cairns et al., 2014) (Figure 2). Interestingly, an R-to-Q substitution at residue 335, confers resistance to the SS55 mAb (Cairns et al., 2014). As for gH, two positively selected sites, Y85 and E170, flanked amino acids that, if mutagenized, confer resistance to the potent LP11 neutralizing antibody (Figure 2) (Chowdary et al., 2010). Because the LP11 antibody competes with gB for binding to the $\mathrm{gH}-\mathrm{gL}$ complex, the gB binding site was proposed to be in close proximity to (or maybe overlapping) with the LP11 epitope surface (Chowdary et al., 2010). E170 is part of this surface, together with other sites we found under positive selection (Figure 2). Overall, these observations suggest that the selective pressure acting on these two glycoproteins is exerted by the host immune system. We also found many positively selected sites in gM (UL10); the N-terminus of gM is predicted to interact with the glycoprotein $\mathrm{N}(\mathrm{gN})$, to form a stable complex, which modulates the viral fusion machinery (El Kasmi and Lippé, 2015). Three of the positively selected sites (S51, R56, P58) we found, are located in the surface exposed region of gM, just upstream the cystein (C59) residue which is responsible for an interchain disulphide bond that stabilize the gM-gN complex (Striebinger et al., 2016), strongly suggesting that these residues could contribute to gM-gN 111 (Figure 2).

112 Among non-core genes showing evidence of positive selection, four (UL46, US8, US1, and US12) 113 are involved in different immune-escape mechanisms. US8 codes for glycoprotein $E(g E)$ that, in 
114 complex with gl, forms an Fc receptor for immunoglobulin G (IgG) (Dubin et al., 1991; Sprague et

115 al., 2006). The gE-gl complex binds the Fc region of IgG leading to an antibody bipolar bridging on

116 infected cells, preventing IgG-mediated immune response. In US8, six positively selected sites were

117 found in the protein domain involved in Fc interaction; among them, E227 and G313 lies at Fc

118 interaction surface boundaries (Figure 3) (Sprague et al., 2006).

119 UL46 encodes an abundant tegument protein that mediates viral evasion from foreign DNA-sensing 120 pathways (Deschamps and Kalamvoki, 2017). In particular, the UL46 protein of HSV-1 interacts with 121 both TMEM173/STING and TBK1 through separate domains and blocks the DNA-sensing pathway.

122 We detected positively selected sites both in the STING and in the TBK1 binding regions (Figure 3).

123 US1 encodes the ICP22 protein (Figure 3), a general transcription regulator that also down-

124 modulates the expression of CD80 in dendritic cells (Matundan and Ghiasi, 2019). Finally, US12

125 encodes the ICP47 protein, which down-regulates the expression of major histocompatibility

126 complex (MHC) class I molecules on the cell surface (Früh et al., 1995; Hill et al., 1995). In

127 particular, the ICP47 proteins of HSV-1 and HSV-2 act as inhibitors of the transporter associated

128 with antigen processing (TAP), which translocates antigenic peptides into the endoplasmic

129 reticulum lumen for loading onto MHC class I (HLA-ABC) molecules (Früh et al., 1995; Hill et al., 130 1995; Tomazin et al., 1998). The TAP-biding region resides in the N-terminal portion of the ICP47

131 protein, where all the positively selected sites are located (Galocha et al., 1997; Matschulla et al.,

132 2017) (Figures 3 and 4A-B).

\section{Positively selected sites in US12 modulate the surface expression of MHC class I molecules.}

135 The N-terminal region of ICP47 is poorly conserved across hominin-infecting SVs, and considerable 136 divergence is also observed between HSV-1 and HSV-2, which however bind and inhibit human TAP 137 (Tomazin et al., 1998). In particular, the $55 \mathrm{~N}$-terminal residues of HSV-1 ICP47 are sufficient to 138 interact with and inhibit TAP (Galocha et al., 1997; Matschulla et al., 2017). Conversely, a previous 139 study indicated that the ICP47 protein encoded by B virus lacks the ability of HLA-ABC down140 regulation, although up-regulation of HLA-E and HLA-G was observed during infection (Vasireddi 141 and Hilliard, 2012). We thus investigated whether the positively selected sites in ICP47 modulate 142 the different ability of simplexvirus proteins to regulate HLA-ABC expression, and if the ICP47 143 protein of B virus is responsible for HLA-G up-regulation. To this aim, we designed constructs 144 carrying the TAP binding domains of HSV-1, HSV-2, or the corresponding region of B virus ICP47. 145 Two additional constructs carried the HSV-1 or HSV-2 ICP47 N-terminal domain mutagenized at the 146 positively selected sites to recapitulate the amino acid state observed in the macaque virus. In 
147 turn, mutations reproducing the amino acids observed in the human virus were introduced in the B

148 virus N-terminal domain (Figure 4B).

149 These constructs, together with a plasmid expressing the full-length HSV-1 ICP47 protein, were

150 transiently transfected in Jurkat cells and the surface expression of HLA-ABC molecules was

151 evaluated by cytofluorimetry. As expected, a significant effect of the plasmids on HLA-ABC

152 expression was evident (ANOVA, $\mathrm{F}=19.55, \mathrm{P}=7.22 \times 10^{-8}$ ), whereas the differences among

153 replicates were not significant $(F=2.57, P=0.08)$. Tukey post hoc tests indicated that the full-

154 length ICP47 protein and the two TAP binding domains of HSV-1 and HSV-2 significantly reduced

155 HLA-ABC expression compared to mock transfected cells (Figure 4C). No difference was observed

156 between the two short constructs and the complete ICP47 protein. Mutation of the positively

157 selected sites in both the HSV-1 and HSV-2 TAP biding domains of ICP47 totally abolished these

158 effects (Figure 4C), suggesting that the selected sites play an important role in TAP binding. In line

159 with previous results (Vasireddi and Hilliard, 2012), the ICP47 domain of B virus did not affect HLA-

$160 A B C$ expression, However, mutation of the selected sites to recapitulate the amino acids observed

161 in the HSV-1/HSV-2 molecules was not sufficient to restore TAP inhibition (Figure 4C). Overall, these

162 results indicate that the positively selected sites are not the sole determinants of TAP binding.

163 We next assessed the effect of the different ICP47 constructs on HLA-G expression. Again, a

164 significant effect for the constructs (ANOVA, $F=53.28, P=5.91 \times 10^{-12}$ ) but not for the replicates ( $F$

$165=0.73, \mathrm{P}=0.55)$ was observed. The short $\mathrm{N}$-terminal domain of $\mathrm{B}$ virus ICP47 was sufficient to

166 significantly increase HLA-G expression compared to mock-transfected cells (Figure 4D). Mutation

167 of the positively selected sites to those observed in HSV-1 and HSV-2 fully abrogated the increased

168 expression of HLA-G. Interestingly, whereas the expression of full or partial HSV-1/HSV-2 ICP47 did

169 not affect HLA-G expression, introduction of mutations that recapitulate amino acids observed in B

170 virus conferred to both ICP47 N-terminal domains the ability to induce HLA-G (Figure 4D). These

171 results indicate that the modulatory effect of $B$ virus on HLA-G expression is mediated by the N-

172 terminal domain of ICP47 and that the positively selected sites are the major determinants of HLA-

173 G regulation. Clearly, the effect on HLA-G expression must be TAP-independent.

\section{Discussion}

177 Primate simplexviruses are often regarded as an epitome of virus-host coevolution and

178 codivergence (Eberle and Jones-Engel, 2017; McGeoch et al., 2006). These viruses establish life-

179 long infections and usually cause little harm to their hosts, whereas periodic viral reactivation 
180 allows transmission in the population. Indeed, virulence and host range are often interconnected 181 traits in viruses (Rothenburg and Brennan, 2020), which are expected to evolve to maximize their 182 transmission potential in the host and to tune their virulence accordingly.

183 Whereas several herpesviruses are unable to infect species other than their natural host, the occasional cross-species transmission of primate simplexviruses has been documented several times, indicating that few barriers exist in terms of infection potential (Azab et al., 2018). However, most spill-overs result in a very severe disease in the new host, especially when the phylogenetic distance from the original host is considerable (Azab et al., 2018). For instance, HSV-1 infection is almost invariably fatal in New World monkeys, whereas limited data on gorillas and Old World monkeys suggest that the symptoms are milder (Gilardi et al., 2014; Tischer and Osterrieder, 2010). The best known example of the severe effects of cross-species transmission is that of B virus. Although the virus is rarely acquired, even in people who are in frequent contact with macaques, mortality due to central nervous system involvement is extremely high when infection occurs (Azab et al., 2018; Eberle and Jones-Engel, 2018; Tischer and Osterrieder, 2010) .

194 These observations clearly indicate that simplexviruses have been adapting to their hosts to balance virulence and transmission. Such a balance is most likely the result of multiple interactions between virus- and host-encoded factors, and the interplay between the host immune response and the viral evasion strategies is expected to determine the outcome of infection. We thus searched for signals of adaptation of simplexviruses to their hominin hosts. Specifically, we applied a branch-site test, which is well-suited to identify episodic positive selection - i.e., selection events that occurred on a specific branch of a phylogeny. Among core genes, we found evidence of episodic positive selection in three glycoproteins, namely gB, gM, and $\mathrm{gH}$, all of which contribute to virus cell entry via membrane fusion (Arii and Kawaguchi, 2018; El Kasmi and Lippé, 2015). For $\mathrm{gB}$ and $\mathrm{gH}$ we found that some of the positively selected sites map to antigenic determinants, suggesting that the host adaptive immune response represents the underlying selective pressure. Moreover, these glycoproteins participate in other processes that contribute to the alteration of the host immune responses. In fact, gB affects the trafficking of MHC class II molecules and diverts them to the exosome pathway (Temme et al., 2010), whereas gH interacts with both $\alpha v \beta 3$-integrin and TLR2, which sense the virus and activate the innate immune response (Gianni et al., 2012;

210 factor for several enveloped viruses(Blondeau et al., 2013; Liu et al., 2015). In line with the view 211 that hosts and viruses are engaged in genetic conflicts, tetherin was shown to have evolved under 212 positive selection in primates (Gupta et al., 2009; Lim et al., 2010; McNatt et al., 2009). Indeed, this 
213 is a general finding for a number of genes involved in defense mechanisms, which display unusually

214 rapid rates of evolution in response to the selective pressure imposed by pathogens (Sironi et al.,

215 2015). Clearly, several infectious agents can insist on the same defense pathway, implying that

216 pathogens are faced with a fast-evolving array of host defense mechanisms. For instance, STING, a

217 stimulator of interferon responsive genes, which is positively selected in primates (Mozzi et al.,

218 2015), is targeted by several viruses. We found three positively selected sites in the STING-binding

219 domain of UL46, suggesting virus adaptation to modulate interaction with the host molecule.

220 Another cellular system commonly antagonized by viruses is the antigen processing and

221 presentation pathway, many components of which show rapid evolutionary rates (Forni et al.,

222 2014). In particular, different herpesviruses employ distinct strategies to interfere with the antigen

223 presentation pathway, thus protecting themselves from the host immune response (van de Weijer

224 et al., 2015; Verweij et al., 2015). In addition to the above-mentioned effect of gB on MHC class II

225 sorting, simplexviruses express the ICP22 protein, which is positively selected and down-modulates

226 CD80 (Matundan and Ghiasi, 2019), as well as the ICP34.5 protein (the product of RL1). ICP34.5, a

227 neurovirulence factor that blocks MHC II expression on the surface of infected cells (Trgovcich et

228 al., 2002). Due to the small number of confirmed orthologs of RL1 we could no test whether

229 positive selection acted on this gene.

230 We instead analyzed the selection pattern of US12, which encodes ICP47. All but one of the

231 positively selected sites we detected were located within the N-terminal domain. For the HSV-1

232 ICP47 protein, this region is sufficient to bind TAP and freeze it in an inactive conformation

233 (Galocha et al., 1997; Matschulla et al., 2017). Because peptide loading is necessary to allow

234 folding of HLA class I molecules in their active configuration, this in turn results in the retention of

235 HLA-ABC molecules in the endoplasmic reticulum. HLA-ABC down-regulation prevents the

236 recognition of infected cells by $\mathrm{CD} 8^{+}$T-lymphocytes, which explains why TAP inhibition is a

237 common viral strategy of immune subversion (Hill et al., 1995). The TAP binding activity of ICP47

238 was demonstrated for both the HSV-1 and HSV-2 proteins, although sequence similarity is limited

239 in the N-terminal portion. Conversely, infection with B virus does not result in the down-

240 modulation of HLA-ABC expression (Vasireddi and Hilliard, 2012). We thus reasoned that the

241 selected sites might underlie the different ability of simplex viruses to inhibit TAP. However, our

242 data indicate that, although the amino acid status at these sites is clearly important, as their

243 mutation in HSV-1/HSV-2 ICP47 restored HLA-ABC expression to the same level as non-transfected

244 cells, they do not represent the sole determinants of TAP binding. In fact, when the amino acids

245 observed in the human viruses were introduced in the $\mathrm{N}$-terminus of $\mathrm{B}$ virus ICP47, no HLA-ABC 
down-modulation was observed. Conversely, the amino acid status at the positively selected sites is sufficient to determine HLA-G up-regulation. In fact, the N-terminal domains of both HSV-1 and HSV-2 ICP47 induced HLA-G when mutated to recapitulate residues in B virus. Conversely, the mutated version of B virus ICP47 failed to determine HLA-G expression. Overall, these results imply that the ability of B virus to induce HLA-G resides in the N-terminal domain of ICP47 and that it does not depend on TAP. This is consistent with the notion that HLA-G can be loaded with peptides by both TAP-dependent and TAP-independent pathways (Lee et al., 1995). The mechanism underlying the up-regulation of HLA-G by B virus ICP47 remains unexplored, and further experiments will thus be required to determine how the positively selected sites exert their effect. As a corollary, our data indicate that the short region of ICP47 we analyzed herein could be used as an inducer of HLA-G expression, which is regarded as a potential biotherapy in allogenic transplantation (Deschaseaux et al., 2011).

258 The reason why related viruses use the same protein to differentially modulate host responses remains to be clarified. The loss of TAP-binding activity by B virus ICP47 may represent a strategy to limit NK cell activation (Vasireddi and Hilliard, 2012). In fact, reduced HLA-ABC expression on the cell surface results in NK-mediated killing, unless inhibitory ligands are also expressed (Früh et al., 1995; Hill et al., 1995; Huard and Früh, 2000). Indeed, NK cells play a central role in limiting HSV1/HSV-2 infection, as demonstrated by mouse models (Rager-Zisman et al., 1987), as well as by the extremely severe infection outcome in humans with genetic defects resulting in low/absent NK cell counts (Orange, 2013). It was instead suggested that B virus, due to its lack of TAP-inhibitory activity, does not trigger NK responses(Vasireddi and Hilliard, 2012). In addition, at least in human cells, this virus up-regulates HLA-G (Vasireddi and Hilliard, 2012), which is associated with diverse immunosuppressive functions, including inhibition of T cell and NK cell responses (Morandi et al., 2016). On one hand these observations might account for the extreme virulence of $B$ virus in humans. On the other, as noted elsewhere(Eberle and Jones-Engel, 2018), they do not explain why

272 ortholog of HLA-G, as it is a pseudogene (Boyson et al., 1997). Through alternative splicing, the 273 Mamu-AG gene of these non-human primates encodes glycoproteins functionally similar to HLA-G 274 (Slukvin et al., 2000), which is also alternatively spliced. Mamu-AG shares several features with 275 human HLA-G, including a role in the establishment of maternal-fetal immune tolerance, but it is 276 phylogenetically more similar to HLA-A (Boyson et al., 1997). It is thus possible that Mamu-AG 277 glycoproteins are not up-regulated by ICP47 and that, therefore, infection in macaques elicits weaker immunomodulatory effects, eventually resulting in mild presentation. Addressing this point 
will require further analyses and the generation of antibodies against Mamu-AG, which are not commercially available.

281 In summary, we performed a genome-wide scan of positive selection on the hominin simplexvirus

282 branch. We detected several positively selected sites, many of which most likely evolved in response to immune-mediated selective pressure. As these sites were positively selected, they are expected to affect some viral traits, as phenotypes are the ultimate target of selection. As a proof of concept, we tested the functional effects of positively selected sites in ICP47. Such sites were found to be sufficient to determine the inability of the viral protein to up-regulate HLA-G expression. Thus, the evolution of ICP47 in HSV-1/HSV-2 determined the loss of an immunosuppressive effect, suggesting that the trait under selection was decreased virulence. This possibility parallels findings in human cytomegalovirus, another herpesvirus, whereby different mechanisms promoting viral temperance were described (Dunn et al., 2003; Mozzi et al., 2020).

291 These analyses may also suggest that closely related viruses finely tune the balance between immunosuppressive and immunostimulatory pathways to promote successful co-existence with

293 their primate hosts.

Materials and Methods

\section{Sequences and alignments}

298 Viral genome sequences were retrieved from the NCBI (http://www.ncbi.nlm.nih.gov/) database. A 299 detailed list of accession number is reported in Table S1. Alignments of whole genome sequences 300 were performed with Progressive MAUVE 2.3.1, using default parameters (Darling et al., 2004; 301 Darling et al., 2010). For each viral genome, we retrieved coding sequences of all annotated ORFs. 302 Orthology was inferred according to MAUVE attribution and to genome annotation.

303 Gene alignments were generated using MAFFT (Katoh and Standley, 2013), setting sequence type 304 as codons. Unreliably aligned codons were filtered using GUIDANCE2 (Sela et al., 2015) with a 305 cutoff of 0.90 (Privman et al., 2012). The resulting alignments were manually inspected. 306 Only reliable one-to-one orthologs were included in the subsequent analyses (Table S3).

\section{Selective patterns in primate-infecting simplexviruses}

309 The average $\mathrm{dN} / \mathrm{dS}$ parameter was calculated using the single-likelihood ancestor counting (SLAC) 310 method (Kosakovsky Pond and Frost, 2005), using a phylogeny of 6 SVs infecting different primate 311 species (Table S1). 
312 Phylogenetic trees were generated with the phyML program (version 3.1), by applying a General

313 Time Reversible (GTR) model plus gamma-distributed rates and 4 substitution rate categories, a

314 fixed proportion of invariable sites, and a BioNJ starting tree (Guindon et al., 2009).

315 Differences in dN/dS among catarrhini-infecting SVs genes grouped on the basis of gene

316 conservation in the Herpesvirales order (Davison, 2007) were evaluated using the Wilcoxon rank

317 sum test.

319 Detection of positive selection in the hominin-infecting simplexvirus lineage

320 We analyzed a viral phylogeny composed of 53 catarrhini-infecting viral strains of Simplexvirus

321 genus. Specifically, we include 22 fully-sequenced strains infecting Old word monkey species (i.e.,

322 macaques and baboons), 1 strain infecting chimpanzee, and 30 strains infecting humans (both HSV-

3231 and HSV-2, $\mathrm{n}=15$ respectively). HSV-1 and HSV-2 strains were selected from clinical isolates with

324 no history of passaging in cell culture, sampled in different countries in order to have an

325 heterogeneous pool of viral genomes representative of the diversity among circulating strains

326 (Table S1).

327 Analyses were performed on the same phylogeny of catarrhini-infecting simplexviruses (see

328 above); for each coding-gene, phylogenetic trees were reconstructed using phyML. Each alignment

329 was screened for the presence of recombination using GARD (Kosakovsky Pond et al., 2006), a

330 genetic algorithm implemented in the HYPHY suite (version 2.2.4). When evidence of

331 recombination was detected ( $p$ value<0.01), the coding alignment was split accordingly; sub-

332 regions were than used as the input for molecular evolution analyses. Only resulting alignments

333 that, after GUIDANCE filtering had a length $\geq 250 \mathrm{nt}$ were considered for subsequent analyses.

334 Episodic positive selection on the Hominin-infecting simplexviruses branch was detected by

335 applying the branch-site likelihood ratio tests from codeml ("test 2") (Zhang et al., 2005). In this

336 test, a likelihood ratio test is applied to compare a model (MA) that allows positive selection on the

337 foreground lineages with a model (MA1) that does not allow such positive selection. Twice the

338 difference of likelihood for the two models $(\Delta \operatorname{lnL})$ is then compared to a $\chi^{2}$ distribution with one

339 degree of freedom (Zhang et al., 2005). The analyses were performed using an F3X4 codon

340 frequency models. An FDR correction was applied to account for multiple tests.

341 To identify sites evolving under positive selection, we used BEB analysis from MA (with a cutoff of

342 0.90) and the Mixed Effects Model of Evolution (Murrell et al., 2012) (MEME, cutoff of 0.1), that

343 allows $\omega$ to vary from site to site and from branch to branch at a site. To limit false positives, only

344 sites confirmed by both methods were considered as positively selected. 


\section{Plasmids}

347 The coding sequences of ICP47 N-terminus from HSV-1 (55aa, YP_009137148), HSV-2 (55aa, 348 YP_009137225.1), and B-virus (56aa, NP_851932) were synthesized and cloned in pCMV6-Entry 349 vector by Origene custom service. The pCMV6 vectors coding for the corresponding mutagenized 350 sequences were synthesized and cloned as well (Figure 4B).

\section{Cell culture and transfection}

353 Jurkat cells were cultured in RPMI complete media without antibiotics and supplemented with $10 \%$ 354 Fetal Bovine Serum (FBS). Cells were cultured at $37^{\circ} \mathrm{C}$ and $5 \% \mathrm{CO}_{2}$ in Forma Steri-Cycle $\mathrm{CO}_{2}$ 355 incubator (Thermo). Every 3 days, cells were split to $0.5-1 \times 10^{6}$ cells $/ \mathrm{ml}$ in a T25 culture flask with 356 fresh media. $\sim 5 \times 10^{5}$ Jurkat cells were electroporated in a solution of R-buffer (100 $\mu \mathrm{L}$; Invitrogen) 357 containing 1ug of plasmid (HSV-1 full, N-term HSV-1, N-term HSV-1-mut N-term HSV-2, N-term 358 HSV-2 mut N-term B virus, N-term B virus mut) using a Neon ${ }^{\circledR}$ Transfection System (Invitrogen) 359 under the recommended electroporation condition ( $1350 \mathrm{~V}, 10 \mathrm{~ms}, 3$ pulse). The transfected cells 360 were then seeded into 24-well plate. All experiments were run in four replicates and cells 361 electroporated without plasmid were considered as the control (mock).

362 Post transfection Jurkat cell viability was $\geq 90 \%$ as determined by an automatic cell counter (Digital 363 Bio, NanoEnTek Inc, Korea).

\section{Immunofluorescent staining and Flowcytometry analysis}

366 PBMCs were stained with HLA-ABC PE (Clone W6/32, eBioscience), and HLA-G PE-Cy7 (Isotype IgG2 367 Mouse, Clone 87G, eBioscience), for $15 \mathrm{~min}$ at room temperature in the dark. After incubation, 368 Jurkat cells were washed and resuspended in PBS.

369 Flow cytometric analyses were performed after 2 days post-transfection using a Beckman Coulter 370 Gallios Flow Cytometer equipped with two lasers operating at 488 and $638 \mathrm{~nm}$, respectively, 371 interfaced with Gallios software and analyzed with Kaluza v 1.2. Two-hundred-thousand events 372 were acquired and gated on HLA-ABC or HLA-G for Jurkat cells.

373 Data were collected using linear amplifiers for forward and side scatter and logarithmic amplifiers 374 for fluorescence (FL)1, FL2, FL3, FL4, and FL5. Samples were first run using isotype control or single 375 fluorochrome-stained preparations for color compensation. Rainbow Calibration Particles 376 (Spherotec, Inc. Lake Forest, IL) were used to standardize flow-cytometry results. 
bioRxiv preprint doi: https://doi.org/10.1101/2020.07.28.226126; this version posted July 29, 2020. The copyright holder for this preprint (which was not certified by peer review) is the author/funder, who has granted bioRxiv a license to display the preprint in perpetuity. It is made available under aCC-BY-ND 4.0 International license.

377 Results were expressed as Mean Intensity Fluorescence (MFI) of HLA-ABC and HLA-G on Jurkat 378 cells.

379

\section{$380 \quad$ Funding}

381 This work was supported by the Italian Ministry of Health ("Ricerca Corrente 2019-2020" to MS,

382 "Ricerca Corrente 2018-2020" to DF)

383

384 Competing interests

385 The authors declare no conflict of interest

386 
bioRxiv preprint doi: https://doi org/10.1101/2020.07.28.226126: this version posted July 29.2020 The copyright holder for this preprint (which was not certified by peer review) is the author/funder, who has granted bioRxiv a license to display the preprint in perpetuity. It is made available under aCC-BY-ND 4.0 International license.

\section{References}

Arii, J., and Kawaguchi, Y. (2018). The Role of HSV Glycoproteins in Mediating Cell Entry. Adv. Exp. Med. Biol. 1045, 3-21.10.1007/978-981-10-7230-7_1.

Arvin, A., Campadelli-Fiume, G., Mocarski, E., Moore, P.S., Roizman, B., Whitley, R., and Yamanishi, K. (2007). Human Herpesviruses. Biology, Therapy, and Immunoprophylaxis (Cambridge: Cambridge University Press).

Azab, W., Dayaram, A., Greenwood, A.D., and Osterrieder, N. (2018). How Host Specific Are Herpesviruses? Lessons from Herpesviruses Infecting Wild and Endangered Mammals. Annu. Rev. Virol. 5, 53-68.10.1146/annurev-virology-092917-043227.

Blondeau, C., Pelchen-Matthews, A., Mlcochova, P., Marsh, M., Milne, R.S., and Towers, G.J. (2013). Tetherin restricts herpes simplex virus 1 and is antagonized by glycoprotein M. J. Virol. 87, 1312413133.10.1128/JVI.02250-13.

Boyson, J.E., Iwanaga, K.K., Golos, T.G., and Watkins, D.I. (1997). Identification of a novel MHC class I gene, Mamu-AG, expressed in the placenta of a primate with an inactivated G locus. J. Immunol. 159, 3311-3321.

Cairns, T.M., Fontana, J., Huang, Z.Y., Whitbeck, J.C., Atanasiu, D., Rao, S., Shelly, S.S., Lou, H., Ponce de Leon, M., Steven, A.C., Eisenberg, R.J., and Cohen, G.H. (2014). Mechanism of neutralization of herpes simplex virus by antibodies directed at the fusion domain of glycoprotein B. J. Virol. 88, 2677-2689.10.1128/JVI.03200-13.

Chowdary, T.K., Cairns, T.M., Atanasiu, D., Cohen, G.H., Eisenberg, R.J., and Heldwein, E.E. (2010). Crystal structure of the conserved herpesvirus fusion regulator complex gH-gL. Nat. Struct. Mol. Biol. 17, 882-888.10.1038/nsmb.1837.

Cooper, R.S., Georgieva, E.R., Borbat, P.P., Freed, J.H., and Heldwein, E.E. (2018). Structural basis for membrane anchoring and fusion regulation of the herpes simplex virus fusogen gB. Nat. Struct. Mol. Biol. 25, 416-424.10.1038/s41594-018-0060-6.

Darling, A.C., Mau, B., Blattner, F.R., and Perna, N.T. (2004). Mauve: multiple alignment of conserved genomic sequence with rearrangements. Genome Res. 14, 13941403.10.1101/gr.2289704. 
Darling, A.E., Mau, B., and Perna, N.T. (2010). progressiveMauve: multiple genome alignment with gene gain, loss and rearrangement. PLoS One 5, e11147.10.1371/journal.pone.0011147.

Davison, A.J. (2007). Comparative analysis of the genomes. In Human Herpesviruses: Biology, Therapy, and Immunoprophylaxis, Arvin, A., Campadelli-Fiume, G., Mocarski, E., Moore, P. S., Roizman, B., Whitley, R. and Yamanishi, K. eds., (Cambridge: Cambridge University Press), Chapter 2, pp. $10-26$.

Deschamps, T., and Kalamvoki, M. (2017). Evasion of the STING DNA-Sensing Pathway by VP11/12 of Herpes Simplex Virus 1. J. Virol. 91, e00535-17. doi: 10.1128/JVI.00535-17. Print 2017 Aug 15.10.1128/JVI.00535-17.

Deschaseaux, F., Delgado, D., Pistoia, V., Giuliani, M., Morandi, F., and Durrbach, A. (2011). HLA-G in organ transplantation: towards clinical applications. Cell Mol. Life Sci. 68, 397404.10.1007/s00018-010-0581-6.

Dubin, G., Socolof, E., Frank, I., and Friedman, H.M. (1991). Herpes simplex virus type 1 Fc receptor protects infected cells from antibody-dependent cellular cytotoxicity. J. Virol. 65, 7046-7050.

Dunn, W., Chou, C., Li, H., Hai, R., Patterson, D., Stolc, V., Zhu, H., and Liu, F. (2003). Functional profiling of a human cytomegalovirus genome. Proc. Natl. Acad. Sci. U. S. A. 100, 1422314228.10.1073/pnas.2334032100 .

Eberle, R., and Jones-Engel, L. (2018). Questioning the Extreme Neurovirulence of Monkey B Virus (Macacine alphaherpesvirus 1). Adv. Virol. 2018, 5248420.10.1155/2018/5248420.

Eberle, R., and Jones-Engel, L. (2017). Understanding Primate Herpesviruses. J. Emerg. Dis. Virol. 3, 10.16966/2473-1846.127. Epub 2017 Jan 31.10.16966/2473-1846.127.

El Kasmi, I., and Lippé, R. (2015). Herpes simplex virus $1 \mathrm{gN}$ partners with gM to modulate the viral fusion machinery. J. Virol. 89, 2313-2323.10.1128/JVI.03041-14.

Farooq, A.V., and Shukla, D. (2012). Herpes simplex epithelial and stromal keratitis: an epidemiologic update. Surv. Ophthalmol. 57, 448-462.10.1016/j.survophthal.2012.01.005.

Forni, D., Cagliani, R., Tresoldi, C., Pozzoli, U., De Gioia, L., Filippi, G., Riva, S., Menozzi, G., Colleoni, M., Biasin, M., Lo Caputo, S., Mazzotta, F., Comi, G.P., Bresolin, N., Clerici, M., and Sironi, M. (2014). An Evolutionary Analysis of Antigen Processing and Presentation across Different Timescales Reveals Pervasive Selection. PLoS Genet. 10, e1004189.10.1371/journal.pgen.1004189; 10.1371/journal.pgen.1004189. 
Früh, K., Ahn, K., Djaballah, H., Sempé, P., van Endert, P.M., Tampé, R., Peterson, P.A., and Yang, Y. (1995). A viral inhibitor of peptide transporters for antigen presentation. Nature 375, 415418.10.1038/375415a0.

Galocha, B., Hill, A., Barnett, B.C., Dolan, A., Raimondi, A., Cook, R.F., Brunner, J., McGeoch, D.J., and Ploegh, H.L. (1997). The active site of ICP47, a herpes simplex virus-encoded inhibitor of the major histocompatibility complex (MHC)-encoded peptide transporter associated with antigen processing (TAP), maps to the NH2-terminal 35 residues. J. Exp. Med. 185, 15651572.10.1084/jem.185.9.1565.

Gianni, T., Leoni, V., Chesnokova, L.S., Hutt-Fletcher, L.M., and Campadelli-Fiume, G. (2012). $\alpha$ Vß3Integrin is a Major Sensor and Activator of Innate Immunity to Herpes Simplex Virus-1. Proc. Natl. Acad. Sci. U. S. A. 109, 19792-19797.10.1073/pnas.1212597109.

Gilardi, K.V., Oxford, K.L., Gardner-Roberts, D., Kinani, J.F., Spelman, L., Barry, P.A., Cranfield, M.R., and Lowenstine, L.J. (2014). Human herpes simplex virus type 1 in confiscated gorilla. Emerg. Infect. Dis. 20, 1883-1886.10.3201/eid2011.140075.

Guindon, S., Delsuc, F., Dufayard, J.F., and Gascuel, O. (2009). Estimating maximum likelihood phylogenies with PhyML. Methods Mol. Biol. 537, 113-137.10.1007/978-1-59745-251-9_6; 10.1007/978-1-59745-251-9_6.

Gupta, R.K., Hué, S., Schaller, T., Verschoor, E., Pillay, D., and Towers, G.J. (2009). Mutation of a single residue renders human tetherin resistant to HIV-1 Vpu-mediated depletion. PLoS Pathog. 5, e1000443.10.1371/journal.ppat.1000443.

Heldwein, E.E., Lou, H., Bender, F.C., Cohen, G.H., Eisenberg, R.J., and Harrison, S.C. (2006). Crystal structure of glycoprotein B from herpes simplex virus 1. Science 313, 217-220.313/5784/217.

Hill, A., Jugovic, P., York, I., Russ, G., Bennink, J., Yewdell, J., Ploegh, H., and Johnson, D. (1995). Herpes simplex virus turns off the TAP to evade host immunity. Nature 375,411 415.10.1038/375411a0.

Huard, B., and Früh, K. (2000). A role for MHC class I down-regulation in NK cell lysis of herpes virus-infected cells. Eur. J. Immunol. 30, 509-515. 10.1002/1521-4141(200002)30:2<509::AIDIMMU509>3.0.CO;2-H. 
bioRxiv preprint doi: https://doi org/10.1101/2020.07 28.226126; this version posted July 29,2020 . The copyright holder for this preprint (which was not certified by peer review) is the author/funder, who has granted bioRxiv a license to display the preprint in perpetuity. It is made available under aCC-BY-ND 4.0 International license.

Katoh, K., and Standley, D.M. (2013). MAFFT multiple sequence alignment software version 7: improvements in performance and usability. Mol. Biol. Evol. 30, 772-780.10.1093/molbev/mst010; 10.1093/molbev/mst010.

Kosakovsky Pond, S.L., and Frost, S.D. (2005). Not so different after all: a comparison of methods for detecting amino acid sites under selection. Mol. Biol. Evol. 22, 1208-1222.msi105.

Kosakovsky Pond, S.L., Posada, D., Gravenor, M.B., Woelk, C.H., and Frost, S.D. (2006). Automated phylogenetic detection of recombination using a genetic algorithm. Mol. Biol. Evol. 23, 18911901.10.1093/molbev/msl051.

Lee, N., Malacko, A.R., Ishitani, A., Chen, M.C., Bajorath, J., Marquardt, H., and Geraghty, D.E. (1995). The membrane-bound and soluble forms of HLA-G bind identical sets of endogenous peptides but differ with respect to TAP association. Immunity 3, 591-600.1074-7613(95)90130-2. Leoni, V., Gianni, T., Salvioli, S., and Campadelli-Fiume, G. (2012). Herpes simplex virus glycoproteins $\mathrm{gH} / \mathrm{gL}$ and $\mathrm{gB}$ bind Toll-like receptor 2, and soluble gH/gL is sufficient to activate NFKB. J. Virol. 86, 6555-6562.10.1128/JVI.00295-12.

Lim, E.S., Malik, H.S., and Emerman, M. (2010). Ancient adaptive evolution of tetherin shaped the functions of Vpu and Nef in human immunodeficiency virus and primate lentiviruses. J. Virol. 84, 7124-7134.10.1128/JVI.00468-10.

Liu, Y., Luo, S., He, S., Zhang, M., Wang, P., Li, C., Huang, W., Hu, B., Griffin, G.E., Shattock, R.J., and $\mathrm{Hu}, \mathrm{Q}$. (2015). Tetherin restricts HSV-2 release and is counteracted by multiple viral glycoproteins. Virology 475, 96-109.S0042-6822(14)00499-1.

Looker, K.J., Magaret, A.S., May, M.T., Turner, K.M., Vickerman, P., Gottlieb, S.L., and Newman, L.M. (2015a). Global and Regional Estimates of Prevalent and Incident Herpes Simplex Virus Type 1 Infections in 2012. PLoS One 10, e0140765.10.1371/journal.pone.0140765.

Looker, K.J., Magaret, A.S., Turner, K.M., Vickerman, P., Gottlieb, S.L., and Newman, L.M. (2015b). Global estimates of prevalent and incident herpes simplex virus type 2 infections in 2012. PLoS One 10, e114989.10.1371/journal.pone.0114989.

Loomis, M.R., O'Neill, T., Bush, M., and Montali, R.J. (1981). Fatal herpesvirus infection in patas monkeys and a black and white colobus monkey. J. Am. Vet. Med. Assoc. 179, 1236-1239. 
bioRxiv preprint doi: https://doi org/10.1101/2020.07 28.226126; this version posted July 29 2020. The copyright holder for this preprint (which was not certified by peer review) is the author/funder, who has granted bioRxiv a license to display the preprint in perpetuity. It is made available under aCC-BY-ND 4.0 International license.

Malito, E., Chandramouli, S., and Carfi, A. (2018). From recognition to execution-the HCMV Pentamer from receptor binding to fusion triggering. Curr. Opin. Virol. 31, 43-51.S1879$6257(18) 30015-4$.

Matschulla, T., Berry, R., Gerke, C., Döring, M., Busch, J., Paijo, J., Kalinke, U., Momburg, F., Hengel, H., and Halenius, A. (2017). A highly conserved sequence of the viral TAP inhibitor ICP47 is required for freezing of the peptide transport cycle. Sci. Rep. 7, 2933-017-02994-5.10.1038/s41598-01702994-5.

Matundan, H., and Ghiasi, H. (2019). Herpes Simplex Virus 1 ICP22 Suppresses CD80 Expression by Murine Dendritic Cells. J. Virol. 93, e01803-18. doi: 10.1128/JVI.01803-18. Print 2019 Feb

\subsubsection{8/JVI.01803-18.}

McGeoch, D.J., Rixon, F.J., and Davison, A.J. (2006). Topics in herpesvirus genomics and evolution. Virus Res. 117, 90-104.S0168-1702(06)00021-9.

McNatt, M.W., Zang, T., Hatziioannou, T., Bartlett, M., Fofana, I.B., Johnson, W.E., Neil, S.J., and Bieniasz, P.D. (2009). Species-specific activity of HIV-1 Vpu and positive selection of tetherin transmembrane domain variants. PLoS Pathog. 5, e1000300.10.1371/journal.ppat.1000300.

Morandi, F., Rizzo, R., Fainardi, E., Rouas-Freiss, N., and Pistoia, V. (2016). Recent Advances in Our Understanding of HLA-G Biology: Lessons from a Wide Spectrum of Human Diseases. J. Immunol. Res. 2016, 4326495.10.1155/2016/4326495.

Mozzi, A., Biolatti, M., Cagliani, R., Forni, D., Dell'Oste, V., Pontremoli, C., Vantaggiato, C., Pozzoli, U., Clerici, M., Landolfo, S., and Sironi, M. (2020). Past and ongoing adaptation of human cytomegalovirus to its host. PLoS Pathog. 16, e1008476.10.1371/journal.ppat.1008476.

Mozzi, A., Pontremoli, C., Forni, D., Clerici, M., Pozzoli, U., Bresolin, N., Cagliani, R., and Sironi, M. (2015). OASes and STING: adaptive evolution in concert. Genome Biol. Evol. 7, 10161032.10.1093/gbe/evv046.

Murrell, B., Wertheim, J.O., Moola, S., Weighill, T., Scheffler, K., and Kosakovsky Pond, S.L. (2012). Detecting individual sites subject to episodic diversifying selection. PLoS Genet. 8, e1002764.10.1371/journal.pgen.1002764.

Oldham, M.L., Grigorieff, N., and Chen, J. (2016). Structure of the transporter associated with antigen processing trapped by herpes simplex virus. Elife 5, 10.7554/eLife.21829.e21829 [pii] 
531 Orange, J.S. (2013). Natural killer cell deficiency. J. Allergy Clin. Immunol. 132, 515-525.S00916749(13)01123-8.

533 Privman, E., Penn, O., and Pupko, T. (2012). Improving the performance of positive selection

534 inference by filtering unreliable alignment regions. Mol. Biol. Evol. 29, 1-

$535 \quad 5.10 .1093 / \mathrm{molbev} / \mathrm{msr} 177$.

536 Rager-Zisman, B., Quan, P.C., Rosner, M., Moller, J.R., and Bloom, B.R. (1987). Role of NK cells in 537 protection of mice against herpes simplex virus-1 infection. J. Immunol. 138, 884-888.

538 Rothenburg, S., and Brennan, G. (2020). Species-Specific Host-Virus Interactions: Implications for 539 Viral Host Range and Virulence. Trends Microbiol. 28, 46-56.S0966-842X(19)30220-3.

540 Sela, I., Ashkenazy, H., Katoh, K., and Pupko, T. (2015). GUIDANCE2: accurate detection of 541 unreliable alignment regions accounting for the uncertainty of multiple parameters. Nucleic Acids 542 Res. 43, W7-14.10.1093/nar/gkv318.

543 Severini, A., Tyler, S.D., Peters, G.A., Black, D., and Eberle, R. (2013). Genome sequence of a 544 chimpanzee herpesvirus and its relation to other primate alphaherpesviruses. Arch. Virol. 158, 545 1825-1828.10.1007/s00705-013-1666-y.

546 Sironi, M., Cagliani, R., Forni, D., and Clerici, M. (2015). Evolutionary insights into host-pathogen 547 interactions from mammalian sequence data. Nat. Rev. Genet. 16, 224-236.10.1038/nrg3905.

548 Slukvin, I.I., Lunn, D.P., Watkins, D.I., and Golos, T.G. (2000). Placental expression of the nonclassical 549 MHC class I molecule Mamu-AG at implantation in the rhesus monkey. Proc. Natl. Acad. Sci. U. S. A. $550 \quad 97,9104-9109.97 / 16 / 9104$.

551 Sprague, E.R., Wang, C., Baker, D., and Bjorkman, P.J. (2006). Crystal structure of the HSV-1 Fc 552 receptor bound to Fc reveals a mechanism for antibody bipolar bridging. PLoS Biol. 4, e148.e148.

553 Striebinger, H., Funk, C., Raschbichler, V., and Bailer, S.M. (2016). Subcellular Trafficking and 554 Functional Relationship of the HSV-1 Glycoproteins N and M. Viruses 8, 83.10.3390/v8030083. 555 Temme, S., Eis-Hübinger, A.M., McLellan, A.D., and Koch, N. (2010). The herpes simplex virus-1 556 encoded glycoprotein B diverts HLA-DR into the exosome pathway. J. Immunol. 184, 236$557 \quad 243.10 .4049 /$ jimmunol.0902192.

558 Tischer, B.K., and Osterrieder, N. (2010). Herpesviruses--a zoonotic threat? Vet. Microbiol. 140, $559 \quad 266-270.10 .1016 /$ j.vetmic.2009.06.020. 
bioRxiv preprint doi: https://doi org/10.1101/2020.07 28.226126. this version posted July 29 2020. The copvriaht holder for this preprint (which was not certified by peer review) is the author/funder, who has granted bioRxiv a license to display the preprint in perpetuity. It is made available under aCC-BY-ND 4.0 International license.

560 Tognarelli, E.I., Palomino, T.F., Corrales, N., Bueno, S.M., Kalergis, A.M., and González, P.A. (2019).

561 Herpes Simplex Virus Evasion of Early Host Antiviral Responses. Front. Cell. Infect. Microbiol. 9, 127.10.3389/fcimb.2019.00127.

563 Tomazin, R., van Schoot, N.E., Goldsmith, K., Jugovic, P., Sempé, P., Früh, K., and Johnson, D.C. 564 (1998). Herpes simplex virus type 2 ICP47 inhibits human TAP but not mouse TAP. J. Virol. 72, 25602563.1747.

566 Trgovcich, J., Johnson, D., and Roizman, B. (2002). Cell surface major histocompatibility complex 567 class II proteins are regulated by the products of the gamma(1)34.5 and U(L)41 genes of herpes simplex virus 1. J. Virol. 76, 6974-6986.0163.

569 Underdown, S.J., Kumar, K., and Houldcroft, C. (2017). Network analysis of the hominin origin of 570 Herpes Simplex virus 2 from fossil data. Virus Evol. 3, vex026.10.1093/ve/vex026.

571 van de Weijer, M.L., Luteijn, R.D., and Wiertz, E.J. (2015). Viral immune evasion: Lessons in MHC 572 class I antigen presentation. Semin. Immunol. 27, 125-137.S1044-5323(15)00018-4.

573 Vasireddi, M., and Hilliard, J. (2012). Herpes B virus, macacine herpesvirus 1, breaks simplex virus tradition via major histocompatibility complex class I expression in cells from human and macaque hosts. J. Virol. 86, 12503-12511.10.1128/JVI.01350-12.

Verweij, M.C., Horst, D., Griffin, B.D., Luteijn, R.D., Davison, A.J., Ressing, M.E., and Wiertz, E.J. (2015). Viral inhibition of the transporter associated with antigen processing (TAP): a striking example of functional convergent evolution. PLoS Pathog. 11, e1004743.10.1371/journal.ppat.1004743.

580 Wertheim, J.O., Smith, M.D., Smith, D.M., Scheffler, K., and Kosakovsky Pond, S.L. (2014).

581 Evolutionary origins of human herpes simplex viruses 1 and 2. Mol. Biol. Evol. 31, 2356-

$582 \quad 2364.10 .1093 / \mathrm{molbev} / \mathrm{msu} 185$.

583 Whitley, R. (2004). Neonatal herpes simplex virus infection. Curr. Opin. Infect. Dis. 17, 243-

$584246.00001432-200406000-00012$.

585 Wilson, R.B., Holscher, M.A., Chang, T., and Hodges, J.R. (1990). Fatal Herpesvirus simiae (B virus) 586 infection in a patas monkey (Erythrocebus patas). J. Vet. Diagn. Invest. 2, 242- 
bioRxiv preprint doi: https://doi.org/10.1101/2020.07.28.226126; this version posted July 29, 2020. The copyright holder for this preprint (which was not certified by peer review) is the author/funder, who has granted bioRxiv a license to display the preprint in perpetuity. It is made available under aCC-BY-ND 4.0 International license.

588 Zhang, J., Nielsen, R., and Yang, Z. (2005). Evaluation of an improved branch-site likelihood method

589 for detecting positive selection at the molecular level. Mol. Biol. Evol. 22, 2472-

$590 \quad 2479.10 .1093 / \mathrm{molbev} / \mathrm{msi237.}$ 


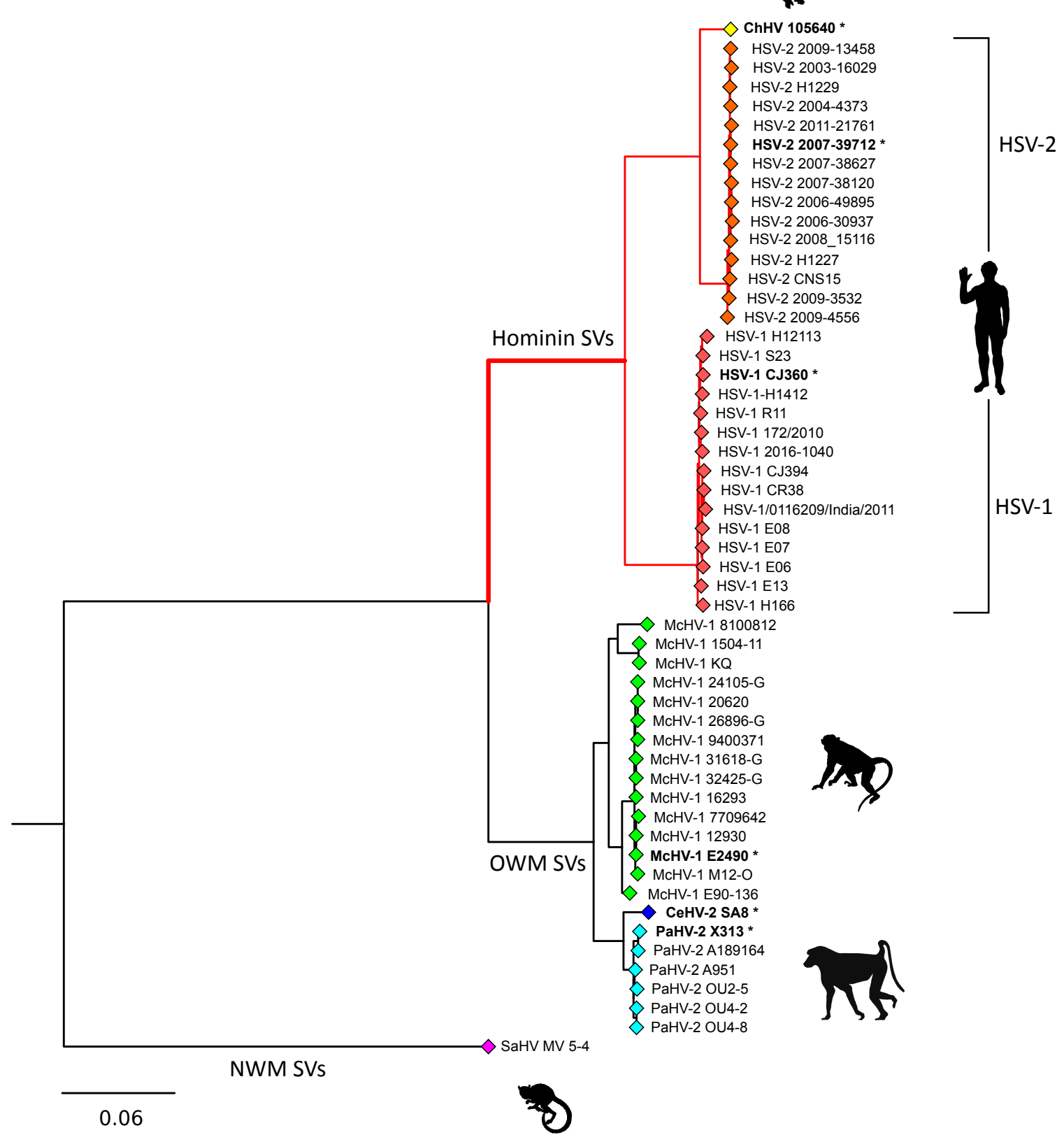

B

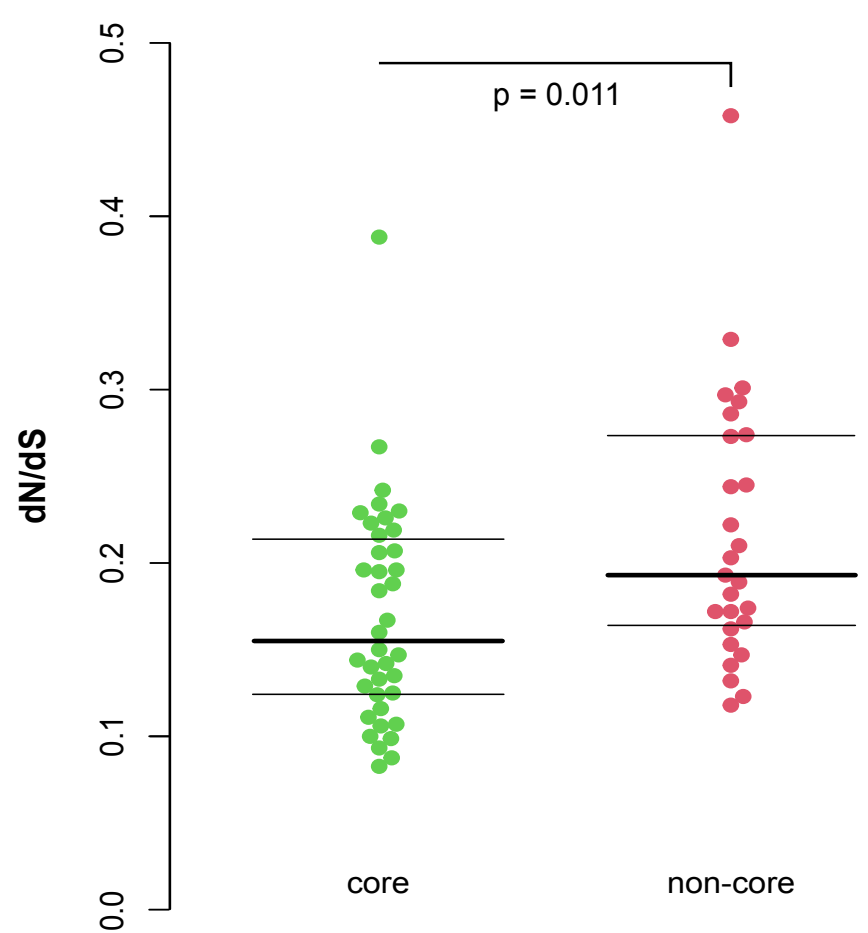

Figure 1. Selective patterns of primate simplexviruses.

(A) A maximum-likelihood tree of glycoprotein B (encoded by the UL27 core gene) is drawn to exemplify the phylogenetic relationships among primate simplexviruses (Strain information and GeneBank IDs are reported in Table S1). The Saimiriine alphaherpesvirus 1 (GeneBank ID: NC_014567) was used as the outgroup and the tree was constructed using PhyML (see methods). Asterisks denote viruses that were included in the analysis of selective patterns of catarrhini-infecting SVs. The hominin simplexvirus branch, that was specifically tested for episodic positive selection, is shown in red. (B) Comparison of $\mathrm{dN} / \mathrm{dS}$ between core and non-core genes. The 
pioRxiv preprint doi: https://doi.org/10.1101/2020.07.28.226126; this version posted July 29, 2020. The copyright holder for this preprint

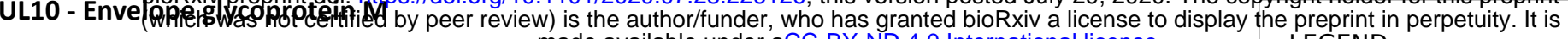

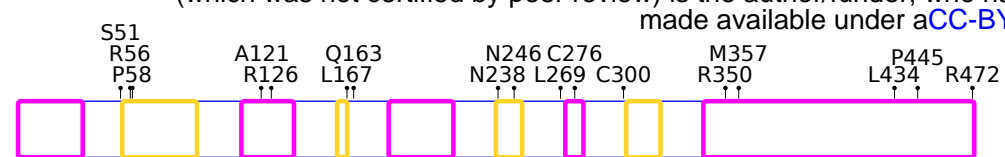

C59: disulfide bond (interchain $\mathrm{gN}$ )

$\mathrm{N}$-term interaction with gN

UL22 - Envelope glycoprotein H

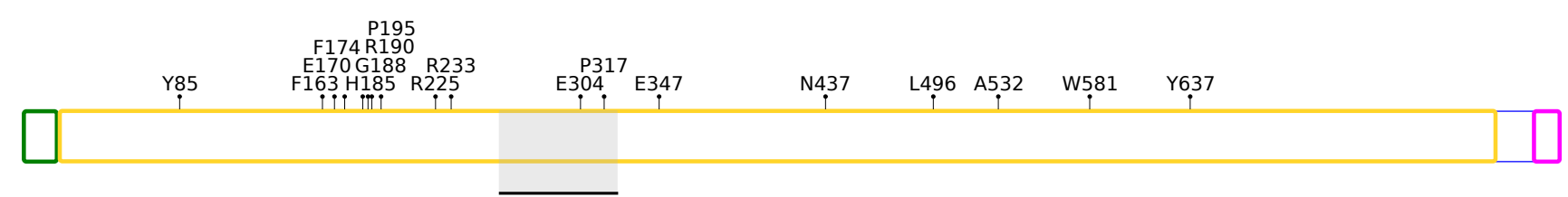

LEGEND:

$\square$ Surface exposed

$\square$ Intravirion or intracellular

$\square$ Transmembrane region

$\square$ Other, mixed or unknown

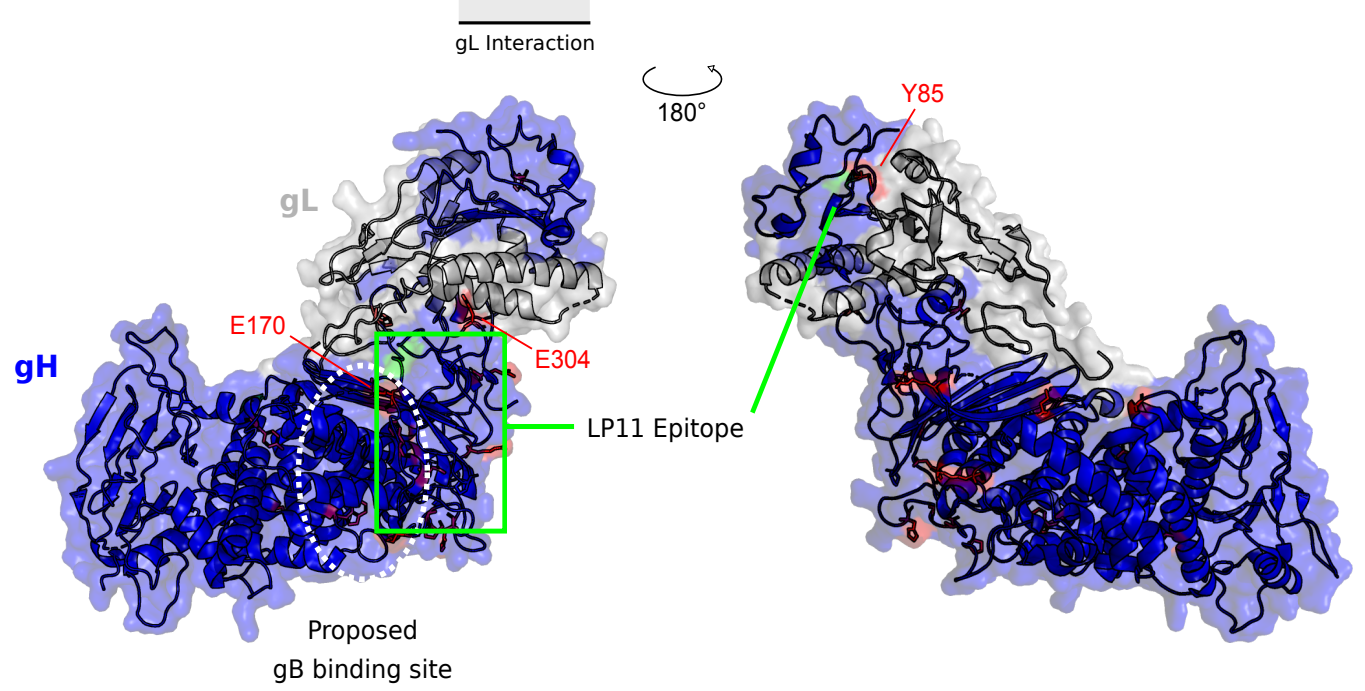

UL27 - Envelope glycoprotein B

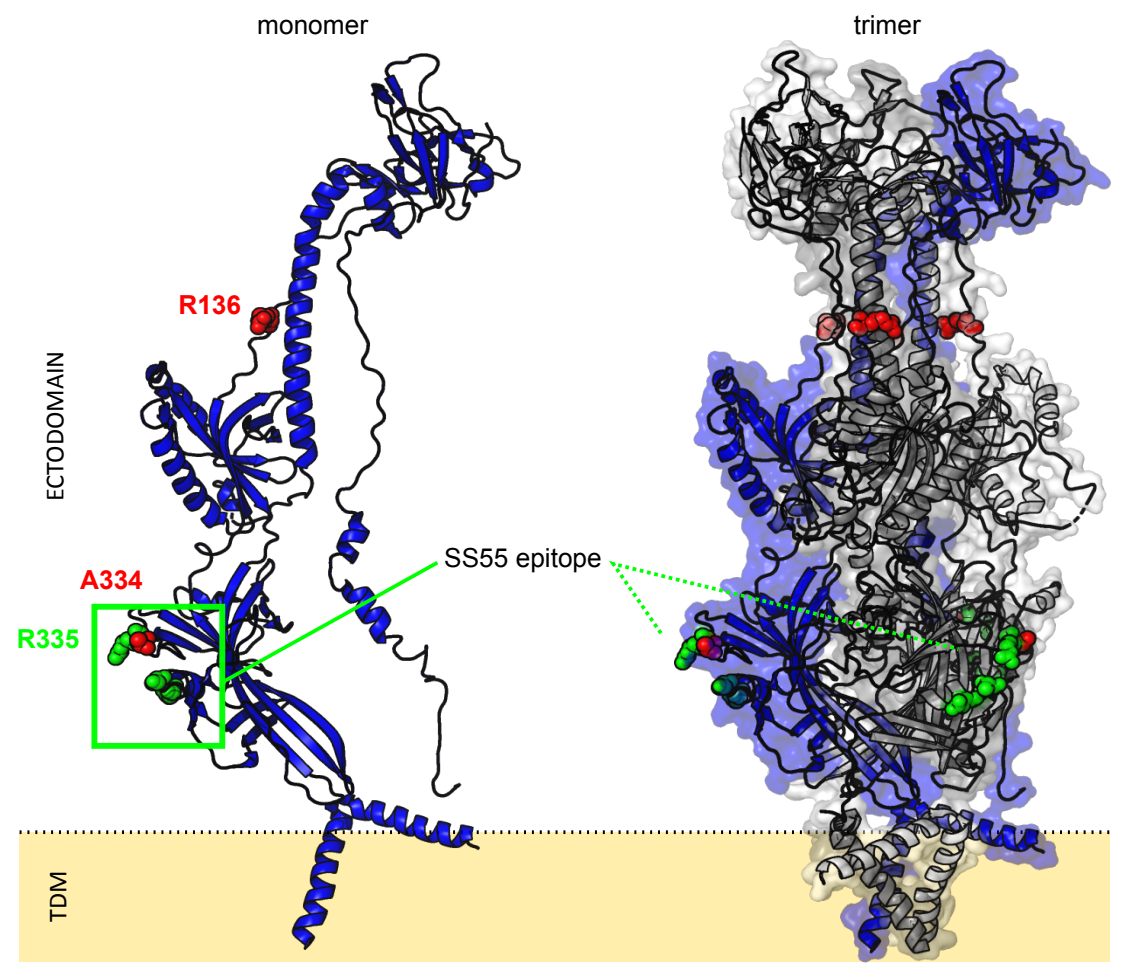

Figure 2. Positive selection in simplexvirus glycoproteins. Positively selected sites were mapped onto HSV-1 glycoproteins together with the location of functional domain/sites (grey). Topological features are color-coded according to the legend. For $\mathrm{gH}$, positively selected sites (red) were mapped onto the three-dimensional structure of the $\mathrm{gH}$-gL complex (blue and white, respectively; PDB ID: 3m1c) (Chowdary et al., 2010). The location of the LP11 epitope (green) and of the gB binding sites (white) are reported. The two views are rotated $180^{\circ}$ around the vertical axis. For gB, positively selected sites were mapped onto the three-dimensional structures of the gB monomer (PDB ID: 6bm8) (Cooper et al., 2018) and the trimeric gB complex. This latter was obtained by a structural imposition of the monomer, using the 2gum structure as scaffold (Heldwein et al., 2006). The location of the SS55 epitope is reported in green. Positions refer to the reference HSV-1 strain 17 (NC_001806). 
bioRxiv preprint doi: https://doi.org/10.1101/2020.07.28.226126; this version posted July 29, 2020. The copyright holder for this preprint

(which was not certified by peer review) is the author/funder, who has granted bioRxiv a license to display the preprint if UL46 - Tegument protein VP11/12 made available under aCC-BY-ND 4.0 International license.

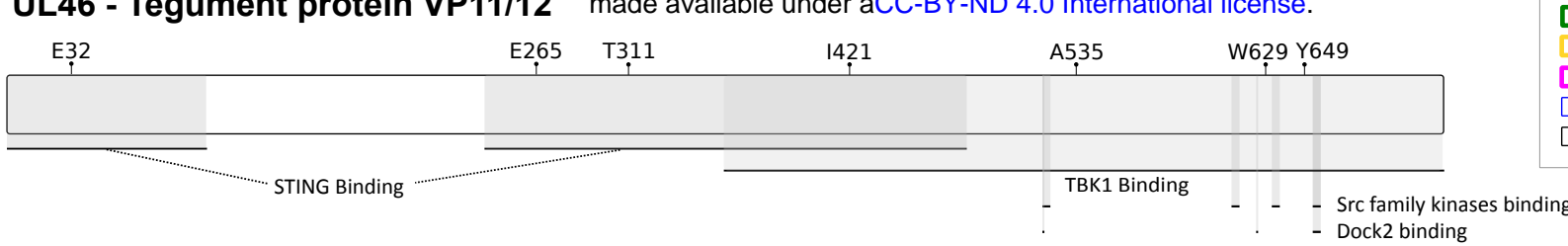

Signal peptide

Surface exposed

$\square$ Intravirion/intracellular

Transmembrane region

$\square$ Other, mixed or unknown

\section{US1 - Regulatory protein ICP22}

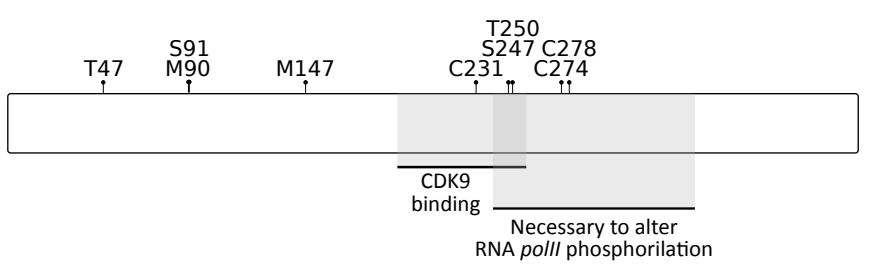

\section{US8 - Envelope glycoprotein E}
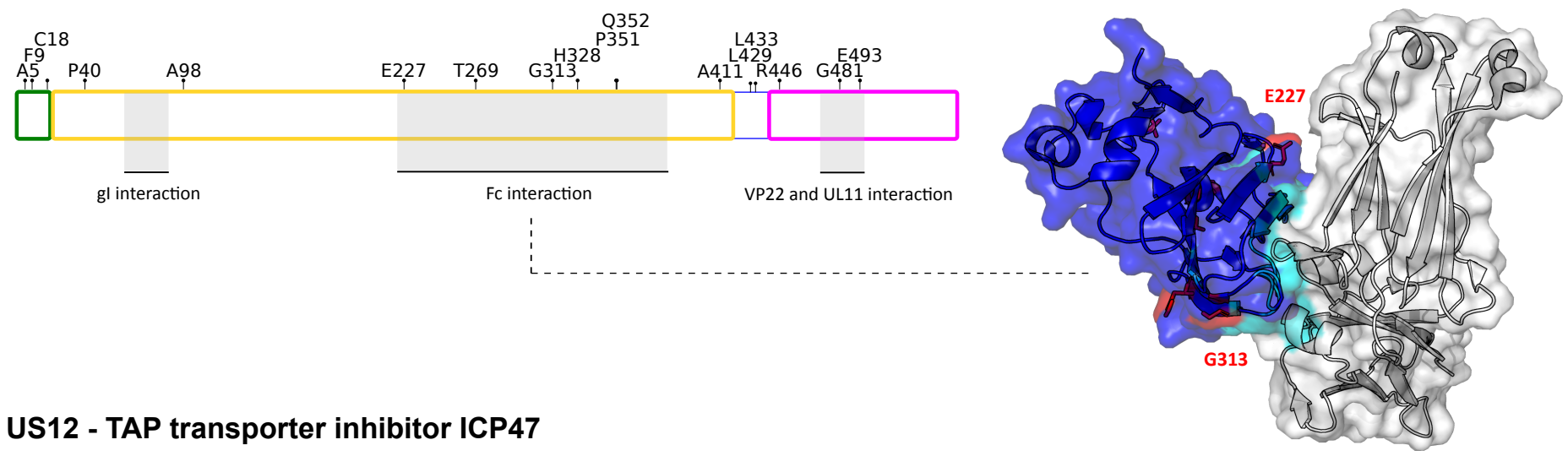

US12 - TAP transporter inhibitor ICP47

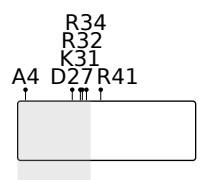

TAP binding

Figure 3. Positive selection in SVs proteins involved in host immune system-escape. Proteins and positively selected sites are reported as in Figure 2. For gE, the three-dimensional structure of the complex with Fc (PDB ID:2gj7) is reported (Sprague et al., 2006). gE is represented in blue, with the Fc interaction surface in cyan. Positively selected sites are in red. Positions refer to the reference HSV-1 strain 17 (NC_001806). 


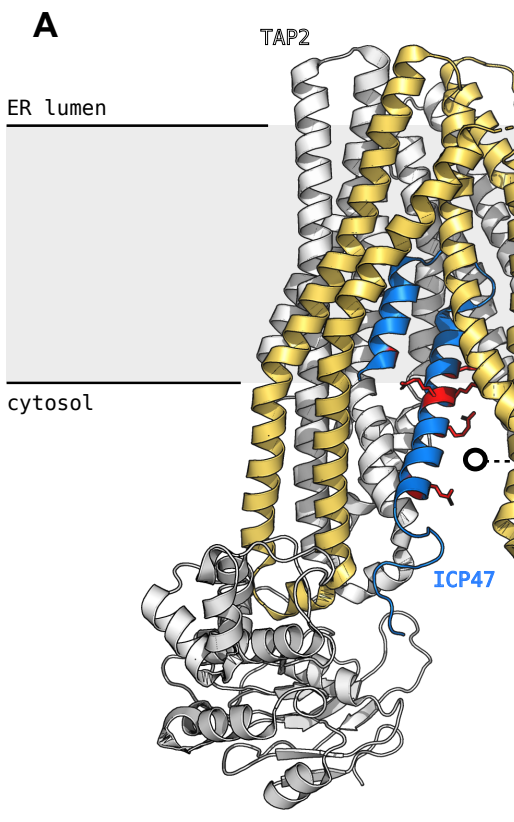

B

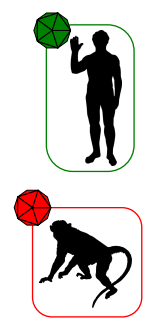

C

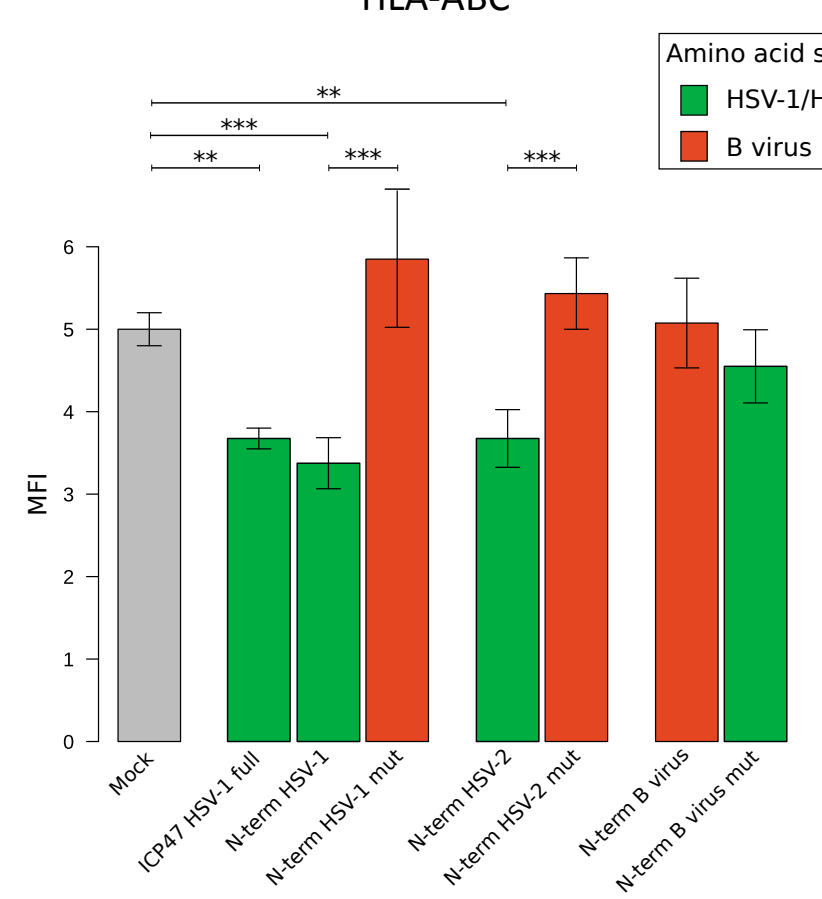

ICP47-HSV1 ICP47-HSV1-mut ICP47-HSV2

ICP47-HSV2-mut

ICP47-B virus ICP47-B virus-mut

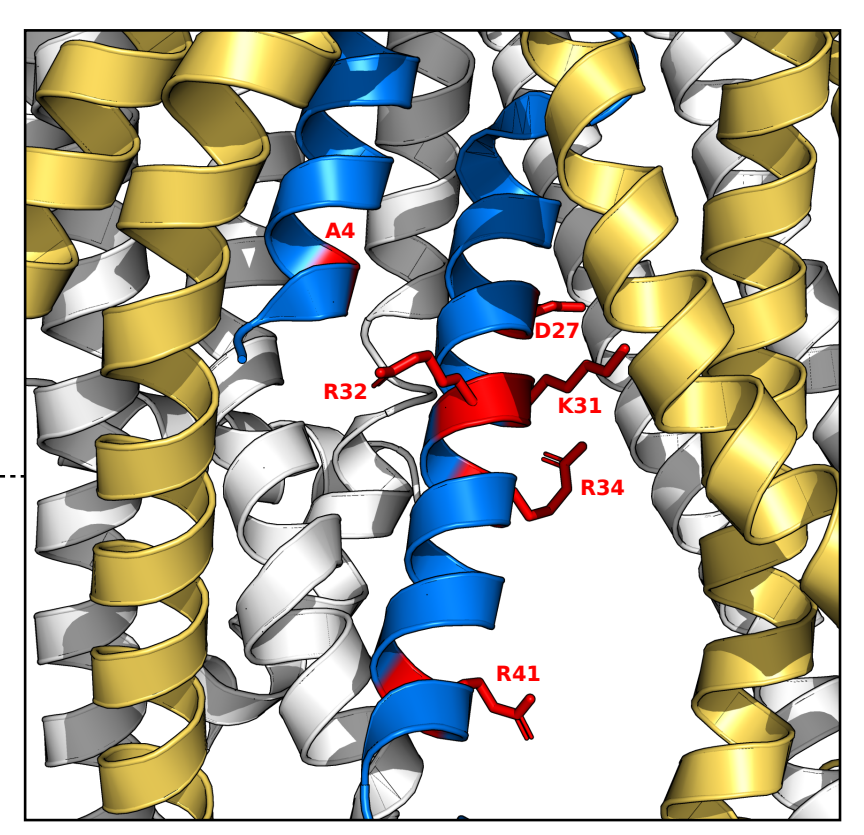

TAP binding domain
MS - WALEMADTFLDTMRVGPRTYADVRDEINKRGREDREAARTAVHDPERPLLRSP

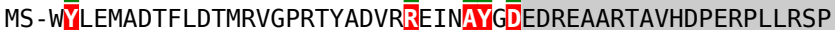
MS - WALKTTDMFLDSSRCTHRTYGDVCAEIHKREREDREAARTAVTDPELPLLC - $P$ MS - WY'LKTTDMFLDSSRCTHRTYGDVCREIHAYEDEDREAARTAVTDPELPLLC - $P$

MSSRYYLAAVDDYLHHPSPRYQAHVDLRRELRAYADEERREAARAIAHPERPLLPPP MSSRÄLAAVDDYLHHPSPRYQAHVDLRDELRKRA

Conserved region

\section{Figure 4. Functional characterization of positive selected sites of US12 (ICP47). (A) Ribbon representation of the}

three-dimensional structure of ICP47 bound to the TAP transporter, which in turn is composed by two subunits, TAP1 (light orange) and TAP2 (white) (PDB ID: 5u1d) (Oldham et al., 2016). Positively selected sites are represented as red sticks in the enlargement. (B) Schematic view recapitulating the amino state of positively selected sites tested in our analyses.

HLA-ABC (C) and HLA-G (D) expression at the cell surface. Jurkat cells were transfected with the ICP47 constructs and the amounts of total HLA-ABC or HLA-G antigen was quantified by cytofluorimetry after 48 hours. MFI (mean fluorescence intensity) bar plots represent the mean and standard deviation of four replicates. $p$ values were calculated using Tukey post hoc tests. 